\title{
Smoking History
}

National Cancer Institute

\section{Source}

National Cancer Institute. Smoking History. NCI Thesaurus. Code C156825.

The history of when and what an individual smoke(s) or smoked. 